\title{
Frequency of births with potentially avoidable serious chromosomal anomalies in EEC countries, 1979-1982
}

\author{
LEO P TEN KATE, ${ }^{1}$ HELEN DOLK, ${ }^{2}$ MARTINA C CORNEL, ${ }^{1}$ PHILIPPE DE WALS, ${ }^{2}$ \\ GERARD J TE MEERMAN, ${ }^{1}$ MICHEL F LECHAT, ${ }^{2}$ AND JOSEPHINE A C \\ WEATHERALL ${ }^{2}$
}

From the Department of Human Genetics, ${ }^{1}$ University of Groningen, the Netherlands; and Department of Epidemiology, ${ }^{2}$ Catholic University of Louvain, Belgium.

With the collaboration of the EUROCAT registry leaders $\mathrm{R}$ BECKERS (West Flanders), I BORLEE (Hainaut), a CAlabro (Umbria), E CAlzolari (Emilia Romagna), c Galanti (Firenze), J GOUjard (Paris), , hamilton (Glasgow), D HANSEN-KOENIG (Luxembourg), F HARRIS (Liverpool), G KARKUT (West Berlin), D F LILLIS (Galway), N NEVIN (Belfast), A RADIC (Dublin), C STOLl (Strasbourg), M ULRICH (Odense).

SUMMARY Child bearing at an early age and prenatal cytogenetic diagnosis in pregnant women of advanced age, combined with selective abortion, make it possible to avoid the birth of many children with serious chromosomal anomalies. To see how many of such births were still avoidable in Europe, data from 16 regional EUROCAT registers of congenital anomalies in nine EEC countries were analysed. In the period 1979-1982 about 30\% of children with unbalanced anomalies of autosomes were born (live- and still-births) to mothers over 35 years of age. This amounts to an estimated 1300 cases yearly in the entire population of the nine countries. The approach shows the possible use of registry data for monitoring effects of avoidance strategies.

As women grow older their risk of having children with chromosomal anomalies increases. ${ }^{1}$ This maternal age effect opens the way to reduction of the number of affected children, either by earlier child bearing or by prenatal cytogenetic diagnosis and selective abortion in older pregnant women.

Some twenty years have elapsed since the early descriptions of prenatal cytogenetic diagnosis. ${ }^{2}{ }^{3}$ Since then numerous services for prenatal diagnosis have been initiated all over the world. Although other reasons for prenatal cytogenetic analysis exist (such as a previous child with aneuploidy, balanced translocation in one of the parents, and sex-linked diseases), the great majority of prenatal cytogenetic diagnoses are done for advanced maternal age. Up to 1981 a collaborative European study had already reported on over 50000 prenatal analyses for this reason. ${ }^{4}$ The introduction of chorionic villus sampling has further stimulated utilisation of prenatal cytogenetic diagnosis. 5

Studies in several parts of the world ${ }^{6-11}$ have, however, shown that utilisation of prenatal cytogenetic diagnosis for advanced maternal age is far from complete. We here report data from 16 population-based registers of congenital anomalies in nine EEC countries in the years 1979-1982. In some European countries there is no legal abortion at any stage of pregnancy. At present in these countries the only way to decrease the number of children with chromosomal anomalies is by encouraging child birth at an earlier age.

\section{Materials and methods}

\section{EUROCAT DATA}

Data on 15036 infants/foetuses with congenital anomalies, born in 16 population-based registers in nine EEC countries in the period 1979-1982, and reported to the central register of EUROCAT (European registration of congenital anomalies) in Brussels, were analysed. EUROCAT is a concerted action programme of the EEC. ${ }^{12}$ Regional population-based registers of congenital anomalies in EEC countries report to the central registry all infants and foetuses from their area with birth defects, detected either prenatally or postnatally, mostly up to the age of 1 year. Diagnoses are provided in words and coded according to the ICD/BPA Classification of Diseases. ${ }^{13}$ The coded information is stored in an automated data base. From this data base we sampled 
all cases with a diagnosis in the category "chromosomal anomalies" (758 in the ICD/BPA Classification). These cases were analysed with regard to diagnostic subcategory and type of birth (live- or still-birth, induced or spontaneous abortion).

\section{CASES EXCLUDED FROM FURTHER ANALYSIS}

The absence or relative mildness of features, and the resulting very incomplete ascertainment of cases with a sex chromosomal anomaly and of individuals with a balanced translocation, caused us to exclude these cases from further analysis. Also excluded were cases with unspecified mosaicism and most other unspecified conditions. Spontaneous abortions were excluded because their reporting was very incomplete. Induced abortions are known to be under-reported by some centres because of privacy protection and/or where procedures take place outside the defined area of study. At least one centre over-reported induced abortions because of referrals from outside the area. In view of these problems induced abortions were also left out of further analysis.

MISSING DATA ON MOTHER'S AGE

In most cases the age of the mother at the time of birth of the case was known precisely. The 35 cases with unknown maternal age were reported from eight out of 16 registries, most commonly in the first year of their reporting. As no other biasing factors appeared to be operating in these cases they were assumed to have the same distribution of maternal age as the cases with known maternal age in the same register and were assigned correspondingly to the appropriate age category.

NATIONAL ESTIMATES AND EXTRAPOLATION TO EEC

From the corrected data the cumulative number and proportion of cases with mother's age above each year

Table 1 EUROCAT registers, 1979-1982, in nine EEC countries, with total births (live-and still-births) surveyed by the registers, total births (live- and still-births) in the country, 1979-1982, and ratio of total births in the country to total number of births surveyed by registers in that country (Data from the United Kingdom are subdivided according to available denominator data)

\begin{tabular}{|c|c|c|c|c|}
\hline $\begin{array}{l}\text { Country and EUROCAT } \\
\text { registry }\end{array}$ & $\begin{array}{l}\text { Period of surveillance } \\
\text { (19-) }\end{array}$ & $\begin{array}{l}\text { Total births surveyed by } \\
\text { registers during this period }\end{array}$ & $\begin{array}{l}\text { Total births in the country } \\
1979-1982\end{array}$ & $\begin{array}{l}\text { Percentage of national births in } \\
\text { register area(s) } 1979-1982\end{array}$ \\
\hline $\begin{array}{l}\text { Belgium } \\
\text { West Flanders } \\
\text { Hainaut }\end{array}$ & $\begin{array}{l}79-82 \\
79-82\end{array}$ & $\begin{array}{l}26293 \\
31613\end{array}$ & 497161 & $11 \cdot 65$ \\
\hline $\begin{array}{l}\text { Denmark } \\
\text { Odense }\end{array}$ & $79-82$ & 19358 & 223608 & 8.66 \\
\hline $\begin{array}{l}\text { France } \\
\text { Paris } \\
\text { Strasbourg }\end{array}$ & $\begin{array}{r}81-82 \\
82\end{array}$ & $\begin{array}{l}77925 \\
13662\end{array}$ & 3190113 & $2 \cdot 87$ \\
\hline $\begin{array}{l}\text { Germany (Fed Republ) } \\
\text { West Berlin }\end{array}$ & $80-82$ & 4614 & 2461184 & 0.19 \\
\hline $\begin{array}{l}\text { Ireland } \\
\text { Dublin } \\
\text { Galway }\end{array}$ & $\begin{array}{l}79-82 \\
81-82\end{array}$ & $\begin{array}{r}84469 \\
6640\end{array}$ & 292352 & $31 \cdot 16$ \\
\hline $\begin{array}{l}\text { Italy } \\
\text { Firenze } \\
\text { Umbria } \\
\text { Emilia Romagna }\end{array}$ & $\begin{array}{l}79-82 \\
79-82 \\
80-82\end{array}$ & $\begin{array}{l}38549 \\
30115 \\
45153\end{array}$ & 2574164 & $4 \cdot 42$ \\
\hline $\begin{array}{l}\text { Luxembourg } \\
\text { Luxembourg }\end{array}$ & $80-82$ & 7015 & 17070 & 41.09 \\
\hline $\begin{array}{l}\text { Netherlands } \\
\text { Groningen }\end{array}$ & $81-82$ & 15640 & 712493 & $2 \cdot 20$ \\
\hline $\begin{array}{l}\text { United Kingdom } \\
\text { England and Wales } \\
\text { Liverpool }\end{array}$ & $79-82$ & 81574 & 2572729 & $3 \cdot 17$ \\
\hline $\begin{array}{l}\text { Northern Ireland } \\
\text { Belfast }\end{array}$ & $79-82$ & 112027 & 112027 & 100 \\
\hline $\begin{array}{l}\text { Scotland } \\
\text { Glasgow }\end{array}$ & $79-82$ & 53152 & 274267 & $19 \cdot 37$ \\
\hline Total & & 647799 & 12927168 & 5.01 \\
\hline
\end{tabular}


of age from 14 to 47 were calculated for live- and still-births and both types combined. Since countries differ in number and proportion of births surveyed by the registers, in the age distribution of pregnant women, and in utilisation of prenatal cytogenetic diagnosis, the combined EUROCAT data do not reflect the precise situation in the nine EEC countries as a whole. In order to arrive at provisional estimates for the total EEC (nine countries), the data from each register or group of registers within a country have been used to calculate the percentage of national births not included in the EUROCAT Register area(s) in each country.

\section{Results}

Not all regional EUROCAT registers have participated in the programme during the whole period. Table 1 shows for each register the period of participation, the number of births surveyed (live- and still-births), the number of births (live- and still-births) in the country or part of the country, ${ }^{14}$ and the percentage of national births in EUROCAT register area(s) in 1979-1982.

Among the 15036 infants/foetuses with congenital anomalies, $1192(7.9 \%)$ were reported with a diagnosis

Table 2 Diagnosis and type of birth in 1192 cases with chromosomal anomalies reported by EUROCAT registers in nine EEC countries, 1979-1982.

( $L B=$ live-birth; $S B=$ still-birth, $S A=$ spontaneous abortion; $I A=$ induced abortion)

\begin{tabular}{|c|c|c|c|c|c|c|}
\hline \multirow[b]{2}{*}{$B P A$ code } & \multirow[b]{2}{*}{ Diagnosis } & \multicolumn{4}{|c|}{ Type of birth } & \multirow[b]{2}{*}{ Total } \\
\hline & & $L B$ & $S B$ & $S A$ & $I A$ & \\
\hline $758 \cdot 0$ & Down's syndrome & 776 & 30 & 1 & 42 & 849 \\
\hline $758 \cdot 1$ & Patau's syndrome & 46 & 5 & - & 3 & 54 \\
\hline $758 \cdot 2$ & Edwards' syndrome & 83 & 21 & 2 & 14 & 120 \\
\hline $758 \cdot 3$ & $\begin{array}{l}\text { Autosomal deletion } \\
\text { syndromes }\end{array}$ & 17 & - & - & 1 & 18 \\
\hline 758.4 & $\begin{array}{l}\text { Balanced autosomal } \\
\text { translocation in } \\
\text { normal individual }\end{array}$ & 6 & - & 1 & - & 7 \\
\hline $758 \cdot 5$ & $\begin{array}{l}\text { Other conditions due to } \\
\text { autosomal anomalies }\end{array}$ & 52 & 2 & 4 & 4 & 62 \\
\hline $758 \cdot 6$ & Gonadal dysgenesis & 28 & - & 4 & 8 & 40 \\
\hline $758 \cdot 7$ & Klinefelter's syndrome & 7 & - & 1 & 7 & 15 \\
\hline $758 \cdot 8$ & $\begin{array}{l}\text { Other conditions due to } \\
\text { sex chromosome anomalies }\end{array}$ & 6 & - & - & 5 & 11 \\
\hline 758.9 & $\begin{array}{l}\text { Conditions due to } \\
\text { anomaly of unspecified } \\
\text { chromosome }\end{array}$ & 14 & 2 & 1 & 1 & 18 \\
\hline 758 & Chromosomal anomalies & 1035 & 60 & 14 & 85 & 1194 \\
\hline
\end{tabular}

in the category "chromosomal anomalies". They represented a fairly constant percentage over the years: 180 cases $(8.8 \%)$ in 1979,269 cases $(7.6 \%)$ in 1980,347 cases $(7 \cdot 5 \%)$ in 1981 , and 396 cases $(8.4 \%)$ in 1982. There was a wide variation in the numbers reported by different registers, ranging from 10 to 220 . Table 2 shows the diagnostic subcategories according to type of birth. The number of diagnoses (1194) slightly exceeds the number of cases (1192), because two cases presented a combination of anomalies in two diagnostic categories: one liveborn infant with trisomy 18 and cri-du-chat syndrome, and one induced abortion with Down's syndrome and Turner's syndrome.

The proportion of induced abortions among sex chromosomal anomalies $(758 \cdot 6-758 \cdot 8)$ is $30.3 \% v$ $5.8 \%$ among autosomal anomalies (758.0-758.3; $758 \cdot 5)$. This difference is due to the absence or relative mildness of postnatal features in sex chromosomal anomalies which results in very incomplete clinical postnatal ascertainment of cases. As described above these cases have therefore been excluded from further analysis, together with unspecified conditions, spontaneous and induced abortions.

After exclusion, a total of 1033 cases remained ( 975 live-births, and 58 still-births), who according to the diagnostic categories were affected with serious mental or physical handicap, or would have been if born alive. In $998(96.6 \%)$ of these 1033 cases the age of the mother at the time of birth of the cases was known precisely. In the remaining 35 cases mother's age was assumed to be equally distributed (see above).

Table 3 is based on the 1033 cases and shows for each country or part of country the total number of live- and still-births with serious autosomal anomalies registered in EUROCAT centres in 1979-1982, as well as the percentages of cases born to mothers above 14 , $19,24,29,34$ years of age and above each year of age from 35 to 47 . The table also shows these figures for the total material and the estimates for the EEC (nine countries). For instance, the percentage of cases with mothers older than 35 years of age is 19 in Belgium, 48 in Ireland, 32 in the total material and an estimated 29 for the EEC. The estimates for the EEC tend to be a few per cent lower than the percentages calculated for the total material, reflecting the relative overpresentation of the countries with many cases in older mothers (such as Ireland and Northern Ireland) in the total EUROCAT material. Data for live births alone (not shown) do not differ substantially from the data for live- and still-births combined.

\section{Discussion}

A variety of preconceptional and prenatal strategies, either preventive or interventive, are available to 
Table 3 Total number and percentages of cases (live- and still-births) with unbalanced autosomal anomalies born to mothers above each year of age from 14 through 47 by (part of) country and extrapolated to the EEC (nine countries), 1979-1982

\begin{tabular}{|c|c|c|c|c|c|c|c|c|c|c|c|c|c|c|c|c|c|c|c|}
\hline \multirow[b]{2}{*}{ Country } & \multirow{2}{*}{$\begin{array}{l}\text { Total number of } \\
\text { cases registered } \dagger \\
1979-1982\end{array}$} & \multicolumn{18}{|c|}{$\begin{array}{l}\text { Percentage of cases* } \\
\text { born to mothers older than (years of age) }\end{array}$} \\
\hline & & 14 & 19 & 24 & 29 & 34 & 35 & 36 & 37 & 38 & 39 & 40 & 41 & 42 & 43 & 44 & 45 & 46 & 47 \\
\hline Belgium & 74 & 100 & 96 & 73 & 41 & 22 & 19 & 12 & 8 & 5 & 5 & 3 & 3 & 1 & - & - & - & - & - \\
\hline Denmark & 20 & 100 & 100 & 70 & 40 & 25 & 20 & 15 & 10 & 10 & 10 & 5 & - & - & - & - & - & - & - \\
\hline England \& Wales & 91 & 100 & 89 & 71 & 46 & 24 & 21 & 16 & 13 & 9 & 5 & 5 & 2 & 2 & 2 & 2 & 1 & - & - \\
\hline France & $127(17)$ & 100 & 98 & 81 & 55 & 32 & 26 & 17 & 16 & 14 & 12 & 8 & 6 & 5 & 5 & 4 & - & - & - \\
\hline Germany & 7 & 100 & 86 & 86 & 71 & 43 & 43 & 43 & 43 & 29 & 14 & - & - & - & - & - & - & - & - \\
\hline Italy & $215(8)$ & 100 & 99 & 80 & 55 & 33 & 27 & 24 & 20 & 18 & 15 & 13 & 7 & 5 & 3 & 1 & - & - & - \\
\hline Ireland & $197(5)$ & 100 & 98 & 89 & 72 & 53 & 48 & 43 & 38 & 31 & 24 & 19 & 14 & 10 & 6 & 3 & 1 & 1 & - \\
\hline Luxembourg & $14(1)$ & 100 & 100 & 69 & 46 & 15 & - & - & - & - & - & - & - & - & - & - & - & - & - \\
\hline Netherlands & $22(4)$ & 100 & 94 & 72 & 50 & 28 & 22 & 11 & 6 & 6 & 6 & 6 & 6 & - & - & - & - & - & - \\
\hline Northern Ireland & 205 & 100 & 95 & 84 & 62 & 43 & 40 & 37 & 31 & 28 & 19 & 16 & 10 & 6 & 3 & 1 & 0 & 0 & 0 \\
\hline Scotland & 61 & 100 & 95 & 72 & 44 & 28 & 25 & 21 & 20 & 16 & 15 & 13 & 11 & 8 & 7 & 3 & 3 & 3 & - \\
\hline Total & $1033(35)$ & 100 & 96 & 81 & 57 & 36 & 32 & 27 & 23 & 20 & 15 & 12 & 8 & 6 & 4 & 2 & 1 & 0 & 0 \\
\hline $\begin{array}{l}\text { EEC } \\
\text { (nine countries) }\end{array}$ & $18945 \ddagger$ & 100 & 94 & 79 & 56 & 33 & 29 & 24 & 22 & 17 & 12 & 8 & 5 & 4 & 2 & 2 & 0 & 0 & 0 \\
\hline
\end{tabular}

reduce the prevalence rate of congenital anomalies at birth. With regard to serious chromosomal anomalies mother's age and the use or non-use of prenatal cytogenetic diagnosis and selective abortion are the main determinants of birth prevalence. Contraceptive measures in older women and/or selective abortion after prenatal cytogenetic diagnosis are, however, not acceptable to everyone and are illegal in some countries. Our data suggest that a substantial proportion of cases with chromosomal anomalies in EEC countries in the years 1979-1982 were born to older mothers. About $30 \%$ (over 1300 cases yearly) were born to mothers over 35 years of age. In some countries this figure even approached $50 \%$.

Our figures, derived from the EUROCAT data base, must be interpreted with some caution. Information on karyotypes is lacking in about $40 \%$ of live- and still-born cases reported with chromosomal anomalies. Although chromosomal analysis may have been done this information frequently is not available to the registries. Where diagnoses have been made on clinical signs and symptoms only, overdiagnosis is possible. On the other hand a certain amount of underdiagnosis or under-reporting cannot be excluded. The continued developments of the EUROCAT registers with strict editing and checking for missing data items should provide more reliable data from 1983 onwards.

Secondly, the extrapolation from EUROCAT data to national and supranational estimates assumes that registry-areas are representative for their countries. This certainly is not the case, since admittance of regional registers to EUROCAT is, among other things, dependent on the availability of high level facilities, such as cytogenetic services and paediatric pathology. On average, health care delivery in registry-areas may be more advanced than in the remainder of the countries. If so, this might result in an underestimation of the number of not-avoided cases in the country and in the EEC total.

Despite these problems in interpretation, the data are sufficient to indicate that a large proportion of births of babies with chromosomal anomalies were still avoidable in EEC countries in the period 19791982. Our analysis also shows the possible use of registry data for monitoring the (combined) effect of avoidance strategies. Analysis of data from 1983 onwards will reveal whether avoidance of these anomalies has made any progress.

The authors are indebted to the many physicians, midwives, nurses and registry clerks in nine EEC 
countries for their assistance over the years in collecting epidemiological data on malformed infants and in developing the methods used in the study. LPTK and MCC were supported by the Dutch Praeventiefonds.

Correspondence to: Dr Leo P Ten Kate, Department of Human Genetics, University of Groningen, The Netherlands.

\section{References}

${ }^{1}$ Hassold T, Chiu D. Maternal age-specific rates of numerical chromosome abnormalities with special reference to trisomy. Hum Genet 1985; 70: 11-7.

2 Steele MW, Breg WR. Chromosome analysis of human amniotic-fluid cells. Lancet 1966; i: 383-5.

3 Jacobson CB, Barter RH. Intrauterine diagnosis and management of genetic defects. Am J Obstet Gynecol 1967; 99: 796-805.

${ }^{4}$ Ferguson-Smith MA, Yates JRW. Maternal age specific rates for chromosome aberrations and factors influencing them: Report of a collaborative European study on 52965 amniocenteses. Prenat Diagn 1984; 4: (special issue): 5-44.

${ }^{5}$ Simoni G, Gimelli G, Cuoco C, et al. First trimester fetal karyotyping: one thousand diagnoses. Hum Genet 1986; 72: 203-9.
${ }^{6}$ Adams MM, Finley S, Hansen $\mathrm{H}$, et al. Utilisation of prenatal genetic diagnosis in women 35 years of age and older in the United States, 1977 to 1978. Am J Obstet Gynecol 1983; 139: 673-7.

${ }^{7}$ Hook EB, Schreinemachers DM. Trends in utilisation of prenatal cytogenetic diagnosis by New York State residents in 1979 and 1980. Am J Public Health 1983; 73: 198-202.

${ }^{8}$ Ferguson-Smith MA. Prenatal chromosome analysis and its impact on the birth incidence of chromosome disorders. Br Med Bull 1983; 39: 355-64.

${ }^{9}$ Mikkelsen M, Fischer G, Hansen J, Pilgaard B, Nielsen J. The impact of legal termination of pregnancy and of prenatal diagnosis on the birth prevalence of Down syndrome in Denmark. Ann Hum Genet 1983; 47: 123-31.

${ }^{10}$ Bell JA, Pearn J, Cohen G, et al. Utilisation of prenatal cytogenetic diagnosis in women of advanced maternal age in Australia, 1979-1982. Prenat Diagn 1985; 5: 53-8.

${ }^{11}$ Baird PA, Sadovnick AD, McGillivray BC. Temporal changes in the utilisation of amniocentesis for prenatal diagnosis by women of advanced maternal age. Prenat Diagn 1985; 5: 191-8.

12 De Wals P, Weatherall JAC, Lechat MF, eds. Registration of congenital anomalies in EUROCAT centres 1979-1983. Cabay: Louvain-la-Neuve, 1985.

${ }^{13}$ British Paediatric Association. Classification of diseases ( $A$ paediatric supplement compatible with the ninth revision of the WHO International Classification of Diseases, 1977). London: BPA, 1979.

${ }^{14}$ United Nations Demographic Yearbook, 1983.

Accepted for publication April 1988 